\title{
Lecturer Mastery Level as an Indicator of Student Satisfaction
} Assessment

\author{
Icuk Rangga Bawono ${ }^{1 *}$, Erwin Setyadi², Apriani Kartika Rahayu ${ }^{3}$ \\ 1,2,3 Accounting Departement, Jenderal Soedirman University, Banyumas, Indonesia \\ *e-mail: cukycutes@yahoo.com
}

\begin{abstract}
The development of the era demands the development of a better and less pragmatic and simplistic mindset and way of teaching in conveying science to its students. The university should now be able to change its paradigm as a site like a company engaged in services offering better service to its customers. It is a quantitative research using a questionnaire model. It analyzes the influence of lecturer competency on student satisfaction levels both directly and through the quality dimensions of services. It also analyzes the most dominant competencies as lecturer competencies. The conclusions that can be drawn from the holding of this research is the ability of the lecturer has an important influence on student satisfaction, the lecturer ability has a significant impact on the level of student satisfaction through the dimension of service quality. Meanwhile, social competence has the most dominant role in shaping the lecturer's competence. It is expected that the results of this study can be considered by lecturers so that they can always develop themselves in order to function more fully.
\end{abstract}

Keywords: Lecturer, Assessment, University, Performance, Student

\section{Introduction}

The higher education level is the continuity of secondary education. The existence of this level aims to make students become a part of society with professional abilities that come from academic experience, who could implement, develop, and create innovation in science, technology, and art. The higher education sector is playing an essential role in developing the economy of almost every nation (Ali et al., 2016; Baragash \& Al-Samarraie, 2018). In the world of education, mostly higher education, tertiary institutions must provide students with a platform to excel and develop their potential and abilities. In short, the achievement is the human ability to develop himself into a better person. One way to become a better person is through the educational process. Higher education will be beneficial to provide more specific knowledge and abilities. We cannot acquire detailed knowledge in high school. However, when someone decides to study at university, things related to science will be more transparent and more understandable. Therefore, universities provide better expertise in knowledge and abilities.

Multiple aspect that needed to be payed attention by lecturer is not far from implementation of basic concept of social learning theory (Bandura, 1977; Lubguban, 2020). These aspects become essential to forming their protégé to reach goal of learning session. Because of its importance, professional teaching competences of teacher or lecturer is needed in the classroom. Not opposite from these theory, Indonesia Government who has national aspirations to educate the nation's children sets basic standards for the teaching force as mentioned in the previous paragraph. Ability to manage protégé and mastering learning material are to make students could adapt and interpreted object or phenomenon around base on what they are studied, this include in the cognitive factor. Competence is important for the individual as an employee in carrying out the duties and responsibilities as an in doing the job. Through knowledge, skill, mastery, professionalism and experience provide a meaningful and tangible sense on job satisfaction (Renyut et al., 2017; Sunengsih, 2015). A noble character that must be have by lecturer is to give a good example for their protégé to imitate it into personal behavior, this include in the behavioral factor. Meanwhile,

\footnotetext{
${ }^{*}$ Corresponding author.
}

Received February 22, 2021; Accepted April 10, 2021; Available online September 25, 2021

Copyright (C) 2021 by Author. Published by Universitas Pendidikan Ganesha.

Jurnal Pendidikan Indonesia (JPI) | 420 
lecturer's social ability to be part of society to give motivation for protégé to able return to the community, this include into environmental factor.

The problem that raise up in the developing country such as Indonesia, many lecturers or academicians have not paid attention to the above problems. They think only of teaching and are practical. The student's conceptualized as a "knowledge recipient", teacher as a direct transmission of knowledge to them (Fauth et al., 2019). Even their way of teaching does not change from time goes by. They are lack of creativity and innovation. Even if there are changes, they are not fundamental though science continues to develop along with the times and levels of human thought. Evidences show that the level of lecturer intelligence in one area is not directly proportional to his ability to present it proportionally to the students. As a consumer of university service products, this will have an impact on student satisfaction. As a measurement service quality provided must be in accordance with customer expectations (Tjiptono \& Chandra, 2011). The satisfaction feeling of customers occurs when the customers felt their expectations fulfilled consider the price has been paid (Chandra et al., 2018). They should conduct massive market surveys in order to identify the particular needs and wants of the customers in this industry (Chuni et al., 2019). In this context, education service quality is an important factor influencing student satisfaction, then it will turn an institutional image (Ali et al., 2016). Good service quality drive satisfy of students, they will loyal to the university (Nguyen et al., 2020). The university's service quality that attain the requirements and needs of students and their expectations have better potential to build a strong relationship with student satisfaction (Dhar \& Sikder, 2018).

As a professional, lecturers are required to be a virtuous human, healthy, knowledgeable, capable, creative, independent, democratic, and responsible for having a high quality of good characters (Maba, 2017; Maba \& Mantra, 2018). The competency-based education implementation remains challenging for educators due to rapid education changes each year and differs strongly between educational programs (Struyven \& De Meyst, 2010; Sturing et al., 2011; van Griethuijsen et al., 2019). This formed from knowledge, skills and work attitude. The competence is equivalent to the rank of someone most uncommon skill, given that the respondent also possess all or most of the other skills with lower rankings (Bech-Larsen \& Tsalis, 2018). Lecturers must have adequate reference books and other academic supports. They must also have the ability to read, observe, research, and discuss and be sensitive to contemporary issues. Not only possess specific knowledge, but lecturers must also develop skills to allow that knowledge to solve specific problems in various conditions (Romanovtseva, 2016). The lecturer's basic competence as a teacher is to manage education in the environment development possible to achieve core competencies (Zvyagin, 2017). A person is said to be competent in his field if his knowledge, skills and attitudes, as well as his work results are in accordance with the institutional standards. Lecturers in the university certainly have competency standards determined by the campus because competence determines the development of learning. A lecturer can also hone these skills by creating a learning community. Professional learning communities have emerged as the most widely believed and the best means of continuously improving teaching instruction and student performance (Schmoker, 2012).

As a service provider for education, higher education is required to provide services that satisfy customers. The ultimate purpose of performing quality service to consumers is to ensure each of them are satisfied with the service experience (Alnazer, 2013). Improvement of service quality of institution is compulsory (Chandra et al., 2018). Customer satisfaction compares people's impressions of product performance (or results) and expectations, which is a person's sense of pleasure or disappointment (Kotler, 2012). In higher education, customer satisfaction begins with expectations of the quality of teaching staff or lecturers (Helgesen \& Nesset, 2007). The results of other studies indicate that the quality of lecturers has a significant impact on student performance (Tella, 2007). Experienced teachers seem to be more effective in teaching basic mathematics and reading in middle schools (Harris \& Sass, 2011). The more experienced teachers' priorities are to develop creative potential and reveal students' capabilities and possibilities through position considerably enhance the chance of his being included in the "children's play society" and allows the development of 
each student (Legankova \& Nedvetskaya, 2016). Competence-based education positively affects pupils' satisfaction with education quality, guidance, and develop interpersonal skills (van Griethuijsen et al., 2019).

In the learning process, pedagogic, professionalism, personality, and social competencies are critical for lecturers to achieve learning success. However, in reality, social competence in current learning lecturers does not pay attention to it. Exact reality showing that the level of intelligence of a lecturer in one area is not directly proportional to his ability to present it proportionally to the students. This is often found in the learning process and shows that the interaction between lecturers and students is less effective and efficient in the learning process. This will have an impact on the student satisfaction of universities as consumers of service products. The higher the competence of human resources will increasingly increase customer loyalty (Megawati et al., 2018). Research reveals that teacher competence has an essential effect that can explain educational quality in Norway (Baumert et al., 2010; Hannås, 2020; Shulman, 1986). Social competence refers to lecturers' ability to effectively communicate and integrate with students, other educators, educators, parents/guardians, and the surrounding community.

This study provides originality issues about importance of lecturer mastery level in their field of specialization. It is a key of strengthening education quality that will drive student satisfaction on study into a higher level. This issue has been elevated, considering there is only a few research universities in the developing country. This research brought expectation to the university, especially lecturers, for increasing the capacity and capability to answer education challenge time goes by. From the background issue, the main problems to discuss in this study are how the competence of lecturers directly affect student satisfaction level, indirectly through the dimensions of service quality, and define the most dominant role competencies in shaping lecturer competency assessments. This study besides contributing to literacy is expected to provide a perspective on its importance of lecturer competence and strengthen quality for student satisfaction in the developing country. Student satisfaction becomes the basis for easier shaping good nation's next generation in developing countries such Indonesia.

\section{Method}

A quantitative methods approach used in this research. This method is a method of quantitative data and objective statistical data obtained through scientific calculations. These data come from a population or sample of residents who are asked to answer any survey questions to determine the frequency and percentage of their responses (Creswell \& Creswell, 2018). The author uses primary data that is processed as a study result. In this study, the researcher obtained the primary data through the results of a questionnaire provided to the students in the survey by filling in a total sample of 500 respondents in the questionnaire. All students currently pursuing D3, S1, S2, and S3 education are set up as a population considered to fit the theoretical framework. The samples used in this study were students who became respondents in the study by filling out a questionnaire given with a total sample of 500 respondents. The questionnaire instrument was adopted and developed from previous research to synchronize with the current research topic.

In this study, the metric used was the Likert scale. In this study, social phenomena have been specifically determined by researchers and are referred to as research variables hereinafter. Likert scale as a guide to transforming respondents' answers of each statement of in the variable into a variable index. Then, use the indicators to arrange tool items, which can be statements or questions. Each tool's answer uses the Likert scale consists of five statements that show strongly agree on symbolled by value " 5 " until strongly disagree symbolled by value " 1 ". This symbolization shows directions of respondents' psychological agreement response of one item issue presented by researchers. It can positively respond or negative responses that can be expressed in the choices. This study's data analysis method is based on a variant structural equation model (SEM) analysis method, namely partial least squares (PLS). 


\section{Result and Discussion}

\section{Results}

Respondent Demographics Data

The demographics of the respondents from the students who participated in this study are presented in Table 1.

Table 1. Respondent Demographics Data

\begin{tabular}{clcc}
\hline No. & \multicolumn{1}{c}{ Aspect/Dimension } & Quantity & Percentage \\
\hline $\mathbf{1}$ & Gender & & \\
& Male & 367 & $73.40 \%$ \\
& Female & 133 & $26.60 \%$ \\
$\mathbf{2}$ & Age & & \\
& $<20$ Years & 41 & $8.20 \%$ \\
& 20 - 25 Years & 103 & $20.60 \%$ \\
& > 25 Years & 356 & $71.20 \%$ \\
$\mathbf{3}$ & Education Level & & \\
& D3 & 41 & $8.20 \%$ \\
& S1 & 187 & $37.40 \%$ \\
& S2 & 249 & $49.80 \%$ \\
& S3 & 23 & $4.60 \%$ \\
& University Status & & \\
& State University & 198 & $39.60 \%$ \\
& Private University & 302 & $60.50 \%$ \\
$\mathbf{5}$ & University Location & & \\
& Java & 295 & $59.00 \%$ \\
& Non-Java Island & 199 & $39.80 \%$ \\
& Foreign Country & 6 & $1.20 \%$ \\
\hline
\end{tabular}

\section{Measurement Model Evaluation}

The reflection index that shows the validity of latent variable can be done with correlate index score and the construction score. PLS result show as in Table 2.

Table 2. Outer Loadings

\begin{tabular}{lrrr}
\hline & $\begin{array}{c}\text { Lecture } \\
\text { Competency (X1) }\end{array}$ & $\begin{array}{c}\text { Service Quality } \\
\text { Dimension (X2) }\end{array}$ & $\begin{array}{c}\text { Student } \\
\text { Satisfaction (Y) }\end{array}$ \\
\hline Pedagogic & 0.892 & & \\
Professional & 0.880 & & \\
Personality & 0.939 & & \\
Social & 0.948 & & \\
Reliability & & 0.904 & \\
Responsiveness & & 0.776 & \\
Assurance & & 0.934 & \\
Empathy & & 0.889 & \\
Tangible & & 0.855 & \\
Satisfaction & & & \\
\hline
\end{tabular}

If the loading value of the correlation is greater than 0.5 , it can be said that the validity of the convergence is satisfied. The output shows that the loading factor value is $>0.5$. Therefore, result reflection index per indicator shows the value that reached convergence validity. 
Table 3. Cross Loadings

\begin{tabular}{lrrr}
\hline & $\begin{array}{c}\text { Lecture } \\
\text { Competency }\end{array}$ & $\begin{array}{c}\text { Service Quality } \\
\text { Dimension (X2) }\end{array}$ & $\begin{array}{c}\text { Student } \\
\text { Satisfaction (Y) }\end{array}$ \\
\hline Pedagogic & $\mathbf{0 . 8 9 2}$ & 0.566 & 0.553 \\
Professional & $\mathbf{0 . 8 8 0}$ & 0.870 & 0.832 \\
Personality & $\mathbf{0 . 9 3 9}$ & 0.632 & 0.570 \\
Social & $\mathbf{0 . 9 4 8}$ & 0.710 & 0.650 \\
Reliability & 0.758 & $\mathbf{0 . 9 0 4}$ & 0.828 \\
Responsiveness & 0.637 & $\mathbf{0 . 7 7 6}$ & 0.695 \\
Assurance & 0.734 & $\mathbf{0 . 9 3 4}$ & 0.900 \\
Empathy & 0.650 & $\mathbf{0 . 8 8 9}$ & 0.790 \\
Tangible & 0.620 & $\mathbf{0 . 8 5 5}$ & 0.724 \\
Satisfaction & 0.734 & 0.934 & $\mathbf{1 . 0 0 0}$ \\
\hline
\end{tabular}

The discriminant validity principle rule states each indicator with a value of load factor above the value of the structure's load factor could be said as valid discriminately. The table shows that each indicator's loading factor has the highest value for the intended construct compared to the loading factor value for other constructs. Therefore, based on Table 3, all indicators show discriminant validity fulfilled.

Table 4. Output Construct Reliability

\begin{tabular}{lrr}
\hline & Cronbach's alpha & Composite reliability \\
\hline Lecture Competency & 0.936 & 0.954 \\
Service Quality Dimension & 0.921 & 0.941 \\
Student Satisfaction & 1.000 & 1.000 \\
\hline
\end{tabular}

Meanwhile, the reliability of the instrument fulfilled if the composite reliability value of each latent variable greater than value 0.7 and Cronbach's alpha reach than 0.7 more. Table 4 shows that the Cronbach's Alpha and Composite Reliability values of all latent variables in this study are $>0.7$. From the result shows in Table 4 latent variables are reliable.

\section{Structural Model Evaluation}

This evaluation to do with the R-squared value analytic. This method is used to measure variability. R-squared change is specifically used to assess specific independent variables' strength relation into a specific dependent variable. The R-squared value of the service quality dimension is 0.610 , indicating that $61 \%$ of the service quality dimension is affected by the ability of the lecturer. The remaining factors are affected by other variables not measured in this study. The R-squared value of student satisfaction is 0.872 , indicating that $87.2 \%$ of student satisfaction is affected by the ability of the lecturer. The remaining factors are affected by other variables not measured in this study.

\section{Significance Test}

The hypothesis test is performed with the process of bootstrap aim to gain a solid picture of the relationship between exogenous on endogenous variables, as shown in Table 5 .

Table 5. Output Bootstrapping

\begin{tabular}{lcccr}
\hline & $\begin{array}{l}\text { Original } \\
\text { Sample }\end{array}$ & Std. Dev & t Statistic & P value \\
\hline $\begin{array}{l}\text { Lecturer competence } \rightarrow \\
\text { service } \\
\text { dimension quality }\end{array}$ & 0.781 & 0.018 & 43.588 & 0.00 \\
Lecturer competence $\rightarrow$ & 0.734 & 0.023 & 31.722 & 0.00
\end{tabular}




\begin{tabular}{|c|c|c|c|c|}
\hline & $\begin{array}{l}\text { Original } \\
\text { Sample }\end{array}$ & Std. Dev & t Statistic & $P$ value \\
\hline student satisfaction & & & & \\
\hline $\begin{array}{l}\text { Service } \\
\text { dimension } \rightarrow \quad \begin{array}{r}\text { quality } \\
\text { satisfaction }\end{array}\end{array}$ & 0.926 & 0.035 & 26.742 & 0.00 \\
\hline
\end{tabular}

\section{Hypothesis test}

The $T$ table value with a confidence level of $95 \%$ ( $\alpha$ is $5 \%$ ) and degrees of freedom (df) $=\mathrm{n}-2=500-2=498$ is 1.647 . The hypothesis test for each latent variable shows as follows: (1) First, based on the results of the significance test in Table 5, the t statistic for the variable of lecturer competence on student satisfaction is $31.722>$ t-table (1.647). Then, the first hypothesis in the study is accepted. This means that the ability of the lecturer has a significant impact on student satisfaction. (2) Second, by calculating the Sobel formula, the indirect influence of the instructor's ability on the level of student satisfaction is tested through the dimension of service quality. Table 10 shows the path coefficient and standard deviation (a) of the relationship between the instructor's ability and the dimension of service quality (a) and the relationship between the dimension of service quality and student satisfaction (b) as shown in Table 6.

Table 6. Path Coefficient and Standard Deviation

\begin{tabular}{lllll}
\hline \multicolumn{2}{c}{$\begin{array}{c}\text { Lecturer competence } \rightarrow \text { service quality } \\
\text { dimension }\end{array}$} & \multicolumn{2}{c}{$\begin{array}{c}\text { Service quality dimension } \rightarrow \text { student } \\
\text { satisfaction }\end{array}$} \\
\hline $\mathrm{A}$ & 0.781 & $\mathrm{~B}$ & & 0.926 \\
Std. Dev a $(\mathrm{Sa})$ & 0.018 & Std. Dev b $(\mathrm{Sb})$ & 0.035 \\
\hline
\end{tabular}

The $t$ count of the performance motivation variable is 22.600 $>t$ table (1.647). By looking at the $t$ count> $t$ table, we can know that the ability of lecturers has a significant impact on the level of student satisfaction through the dimension of service quality. Therefore, the second hypothesis of this study is accepted.

\section{Discussion}

Consumers satisfaction tightly relate to marketing strategic to draw them using one specific product from entity. Almost recent study discuss about consumers satisfaction in business world (Aisyah, 2018; Hammoud et al., 2018; Megawati et al., 2018). As a measurement service quality provided must be in accordance with customer expectations (Tjiptono \& Chandra, 2011). The satisfaction feeling of customers occurs when the customers felt their expectations fulfilled consider the price has been paid (Chandra et al., 2018). The change pattern of the Customers, a significant shift has been observed in the demands and expectations of the customers through service. Knowing the level of the satisfaction apparent by the services consumers can be an advantage in the future by making more appropriate services or changing the way personnel communicates with the consumers (Asnawi et al., 2019). The satisfied customers share their positive experiences with others and become the source of word-of-mouth advertising. In different perspective, unsatisfied customers share negative word-of-mouth and more likely switch to other products or services (Aisyah, 2018).

Product that provide by entity not only in the form of things, but it could be service that presented to others. Education service provide by school or campus become a simple form of the consumer product delivery mechanism, which is none other than the student. The major education problem that often highlighted in the developing country such as Indonesia is that a lot of lecturers or academicians have not paid attention their teaching competence. They forgot to improve their creativity and innovation even though there are changes. Evidences show that lecturer intelligence level in one area to another is not directly proportional ability to present it to the students. As a consumer of university service products, 
this will have an impact on student satisfaction. Study about academic matters it so unwell know by broad people, but there's some study founded elevated topic about education field such (Mulyono et al., 2020; Razinkina et al., 2018). Unfortunately, there is no study that try to present it in developing country such Indonesia. Student satisfaction as an element of monitoring the quality of education in innovative higher education institution, this crucial matter to triggering better human resources in Indonesia.

From result that already show in previous section, lecturer's competency become essential to give student learning experiences satisfaction. As theorized, lecturers' competence predicts student satisfaction of lecturing (Opatha, 2020). The lecturer's basic competence as a teacher is to manage education in the environment development possible to achieve core competencies (Zvyagin, 2017). Lecturer must have the ability to read, observe, research, and discuss and be sensitive to contemporary issues. Competence is important for the lecturer as university employee in carrying out the duties and responsibilities as an in doing the job. Through knowledge, skill, mastery, professionalism and experience provide a meaningful and tangible sense on job satisfaction of employees (Renyut et al., 2017). When a provider delivers service, understanding and adhering to the context of a consumers situation with a complex combination of knowledge, attitudes, and skills (Hudak et al., 2018). Not only possess specific knowledge, but lecturers must also develop skills to allow that knowledge to solve specific problems in various conditions (Romanovtseva, 2016). Someone that can be said competent when his or her knowledge, skills and attitudes, as well as his work results are in accordance with the institutional standards. Student satisfaction as an element of education quality monitoring in innovative higher education institutions Professional learning communities have emerged as the most widely believed and the best means of continuously improving teaching instruction and student performance (Schmoker, 2012).

When lecturer has enough competence on specific field, it will show lecturer individual teaching quality to the students. It shows on the result that quality of lecturer would raise up when lecturer competency also raising up in line with students' satisfaction. Competencies possessed by each employee of the company could provide good service to customers (Harahap et al., 2020). Service quality emphasizes the aspects of the final result (service products) and the quality of human resources, the production process and the environment (Goetsch \& Davis, 2016). The ultimate purpose of performing quality service to consumers is to ensure each of them are satisfied with the service experience (Alnazer, 2013). Customer satisfaction compares people's impressions of product performance (or results) and expectations, which is a person's sense of pleasure or disappointment (Kotler, 2012). If consumers' quality of service is below their needs and expectations, they are not satisfied and disappointed. Therefore, they will stop dealing with service providers. University as management must ensure that customer meets there's expectation through the quality service (Kharde \& Chaudhari, 2019). The staff instantly need to address the quality of their services and how the user satisfaction can be improved (Afthanorhan et al., 2019).

Students are categorized as customers because they have paid for educational services to study. This is also accompanied by the educational process's expectations, such as services, facilities, quality of lecturers, and leadership. Lecturers in the university certainly have competency standards determined by the campus because competence determines the development of learning. A lecturer can also hone these skills by creating a learning community. If lecturers provide more information/explain in one direction without the intonation of a voice the students are rarely allowed to express their free opinions and ask questions. As a result, students become passive and cause the learning process to be less enjoyable. The level of intelligence of a lecturer in one area is not directly proportional to his ability to present it proportionally to the students. This is often found in the learning process and shows that the interaction between lecturers and students is less effective and efficient in the learning process. This have an impact on the student satisfaction of universities as consumers of service products. With social intelligence, teachers will find it easier to manage a class and learning process, as a lecturer is required to be a central figure who is strong and authoritative, but still friendly (Syah, 2013). 


\section{Conclusions and Suggestions}

The results of the research on the level of the instructor's mastery as an indicator of student satisfaction show that: One kind. The ability of the lecturer has an important influence on student satisfaction. The lecturer's ability significantly affects student satisfaction level through the dimension of service quality. Social competence is the competency that has the most dominant role in shaping the lecturer competence assessment. Without prejudice to the conclusions made, this manuscript provides some relatable recommendations such as improving lecturer competence is necessary to improve student satisfaction as service users for services provided by the university. Even though improving lecturer competence is pricy, its human and financial investment creates the lecturer's social reform as a teacher and academia. Efforts to improve services need to pay attention to various aspects related to the dimensions of service quality so that service improvement becomes more focused. As the main component of the lecturer's ability, the social ability focuses on attention and other ability elements to improve university lecturers' quality as educators. Efforts to meet students' interests and satisfaction need to be done through evaluation of service performance through requests for feedback from students. An evaluation is carried out measured by service attributes to determine the weakness or insufficiency of the learning process's service performance.

\section{Acknowledgements}

Authors declare that this work is an original work and will not be republished or published elsewhere. Authors convinced that this research article mainly deals with educational issues (especially teaching and learning) and is related to this journal's purpose.

\section{References}

Afthanorhan, A., Awang, Z., Rashid, N., Foziah, H., \& Ghazali, P. L. (2019). Assessing the effects of service quality on customer satisfaction. Management Science Letters. https://doi.org/10.5267/j.msl.2018.11.004.

Aisyah, M. (2018). Islamic Bank Service Quality and Its Impact on Indonesian Customers' Satisfaction and Loyalty. Al-lqtishad: Jurnal IImu Ekonomi Syariah. https://doi.org/10.15408/aiq.v10i2.7135.

Ali, F., Zhou, Y., Hussain, K., Nair, P. K., \& Ragavan, N. A. (2016). Does higher education service quality effect student satisfaction, image and loyalty?: A study of international students in Malaysian public universities. Quality Assurance in Education. https://doi.org/10.1108/QAE-02-2014-0008.

Alnazer, M. (2013). The moderating role of promotional benefit level and brand awareness on the effectiveness of price discount and premium. International Journal of Business and Management Invention.

Asnawi, A. A., Awang, Z., Afthanorhan, A., Mohamad, M., \& Karim, F. (2019). The influence of hospital image and service quality on patients' satisfaction and loyalty. Management Science Letters. https://doi.org/10.5267/j.msl.2019.2.011.

Bandura, A. (1977). Social Learning Theory. Prentice Hall.

Baragash, R. S., \& Al-Samarraie, H. (2018). Blended learning: Investigating the influence of engagement in multiple learning delivery modes on students' performance. Telematics and Informatics, 35(7), 2082-2098. https://doi.org/10.1016/j.tele.2018.07.010.

Baumert, J., Kunter, M., Blum, W., Brunner, M., Voss, T., Jordan, A., Klusmann, U., Krauss, S., Neubrand, M., \& Tsai, Y. M. (2010). Teachers' mathematical knowledge, cognitive activation in the classroom, and student progress. American Educational Research Journal. https://doi.org/10.3102/0002831209345157.

Bech-Larsen, T., \& Tsalis, G. (2018). Impact of cooking competence on satisfaction with food-related life: Construction and validation of cumulative experience \& knowledge scales. Food Quality and Preference. https://doi.org/10.1016/j.foodqual.2018.02.006. 
Chandra, T., Ng, M., Chandra, S., \& Priyono. (2018). The effect of service quality on student satisfaction and student loyalty: An empirical study. Journal of Social Studies Education Research. https://doi.org/10.17499/jsser.12590.

Chuni, L., Tham, J., \& Azam, S. M. F. (2019). Corporate Competence Determining Factors In China Telecom Industry In Achieving Customer Satisfaction. European Journal of Management and Marketing Studies, 4(3), 75-101. https://doi.org/10.5281/zenodo.3558806.

Creswell, J. W., \& Creswell, J. D. (2018). Research and Design Qualitative, Quantitative and Mixed Methods Approaches. In Thousand Oaks California.

Dhar, B. K., \& Sikder, M. R. (2018). Influencing Factors Of Service Quality On Students' Satisfaction At Universiti Sains Islam Malaysia (USIM), Malaysia. International Journal of Business Society, 2(12), 01-11. https://doi.org/10.30566/ijo-bs/2018.2121.

Fauth, B., Decristan, J., Decker, A. T., Büttner, G., Hardy, I., Klieme, E., \& Kunter, M. (2019). The effects of teacher competence on student outcomes in elementary science education: The mediating role of teaching quality. Teaching and Teacher Education. https://doi.org/10.1016/j.tate.2019.102882.

Goetsch, D. L., \& Davis, S. B. (2016). Quality Management for Organizational Excellence: Introduction to Total Quality. Pearson.

Hammoud, J., Bizri, R. M., \& El Baba, I. (2018). The Impact of E-Banking Service Quality on Customer Satisfaction: Evidence From the Lebanese Banking Sector. SAGE Open, 8(3), 1-12. https://doi.org/10.1177/2158244018790633.

Hannås, B. M. (2020). Expert assessments regarding teacher competence and educational settings for special needs education in Norwegian schools. Psykologi i Kommunen, 6, $1-11$.

Harahap, R. A., Priscilla, F., Wijaya, M., \& Shellin. (2020). Effect of competence, communication and job stress towards service quality PT . Sukses Motor Globalindo. Journal of Research in Business, Economics, and Education.

Harris, D. N., \& Sass, T. R. (2011). Teacher training, teacher quality and student achievement. Journal of Public Economics. https://doi.org/10.1016/j.jpubeco.2010.11.009.

Helgesen, Ø., \& Nesset, E. (2007). What accounts for students' loyalty? Some field study evidence. In International Journal of Educational Management. https://doi.org/10.1108/09513540710729926.

Hudak, N. C., Carmack, H. J., \& Smith, E. D. (2018). Student perceptions of providers' cultural competence, attitudes towards providers, and patient satisfaction at a university health center: International and U.S. student differences. Journal of International Students. https://doi.org/10.5281/zenodo.1250395.

Kharde, S. D., \& Chaudhari, A. (2019). Impact of Service Quality on Customer Satisfaction in Hotel Industry: The Comprehensive Study. International Multidisciplinary EResearch Journal, November(Special Issue 207 (A)), 294-296.

Kotler, P. (2012). Marketing management/Philip Kotler, Kevin Lane Keller. Pearson Education International.

Legankova, O. V., \& Nedvetskaya, T. M. (2016). Teacher's Professional Gaming Competence as a Condition for Preschool Education Quality Enhancement. Procedia - Social and Behavioral Sciences. https://doi.org/10.1016/j.sbspro.2016.10.141.

Lubguban, M. G. B. (2020). Leadership proficiency and emotional competence of women school administrators. Journal of Critical Reviews, 7(11). https://doi.org/10.31838/jcr.07.11.47.

Maba, W. (2017). Teacher's perception on the implementation of the assessment process in 2013 curriculum. International Journal of Social Sciences and Humanities. https://doi.org/10.29332/ijssh.v1n2.26.

Maba, W., \& Mantra, I. B. N. (2018). The primary school teachers' competence in implementing the 2013 curriculum. SHS Web of Conferences. https://doi.org/10.1051/shsconf/20184200035.

Megawati, T., Rofiaty, \& Hadiwidjojo, D. (2018). Role of Trust and Customer Satisfaction as a 
Mediation Effect of Human Resource Competence on Customer Loyalty (Study on Commercial Customer BCA Kanwil VII Malang). Wacana, 21(1), 34-41.

Mulyono, H., Hadian, A., Purba, N., \& Pramno, R. (2020). Effect of Service Quality Toward Student Satisfaction and Loyalty in Higher Education. Journal of Asian Finance, Economics and Business, 7(10), 929-938.

Nguyen, D. T., Pham, V. T., Tran, D. M., \& Pham, D. B. T. (2020). Impact of Service Quality, Customer Satisfaction and Switching Costs on Customer Loyalty. The Journal of Distribution Science, 7(8), 395-405.

Opatha, H. H. D. N. P. (2020). Influence of lecturers' competence on students' satisfaction of lecturing: Evidence for mediating role of lecturing behaviour. Universal Journal of Educational Research. https://doi.org/10.13189/ujer.2020.080406.

Razinkina, E., Pankova, L., Trostinskaya, I., Pozdeeva, E., Evseeva, L., \& Tanova, A. (2018). Student satisfaction as an element of education quality monitoring in innovative higher education institution. E3S Web of Conferences. https://doi.org/10.1051/e3sconf/20183303043.

Renyut, B. C., Modding, H. B., Bima, J., \& Sukmawati, S. (2017). The effect of organizational commitment, competence on Job satisfaction and employees performance in Maluku Governor's Office. IOSR Journal of Business and Management (IOSR-JBM), 19(11), 18-29. https://doi.org/10.9790/487X-1911031829.

Romanovtseva, O. V. (2016). The Competence Approach in Education. Contemporary Problems of Social Work, 2(4), 83-91. https://doi.org/10.17922/2412-5466-2016-2-483-91.

Schmoker, M. (2012). The madness of teacher evaluation frameworks. Phi Delta Kappan. https://doi.org/10.1177/003172171209300817.

Shulman, L. S. (1986). Those Who Understand: Knowledge Growth in Teaching. Educational Researcher, 15(2), 4-14. https://doi.org/10.3102/0013189X015002004.

Struyven, K., \& De Meyst, M. (2010). Competence-based teacher education: Illusion or reality? An assessment of the implementation status in Flanders from teachers' and students' points of view. Teaching and Teacher Education. https://doi.org/10.1016/j.tate.2010.05.006.

Sturing, L., Biemans, H. J. A., Mulder, M., \& de Bruijn, E. (2011). The Nature of Study Programmes in Vocational Education: Evaluation of the Model for Comprehensive Competence-Based Vocational Education in the Netherlands. Vocations and Learning. https://doi.org/10.1007/s12186-011-9059-4.

Sunengsih, N. D. (2015). Hubungan Profesionalisme, Iklim Sekolah, Dan Integritas Dengan Kinerja Guru SMP Negeri Di Kota Administrasi Jakarta Timur. Jurnal Manajemen, 19(2), 190-204. https://doi.org/10.24912/jm.v19i2.123.

Syah, M. (2013). Psikologi Pendidikan Dengan Pendekatan Baru. Pt Remaja Rosdakarya.

Tella, A. (2007). The impact of motivation on student's academic achievement and learning outcomes in mathematics among secondary school students in Nigeria. Eurasia Journal of Mathematics, Science and Technology Education. https://doi.org/10.12973/ejmste/75390.

Tjiptono, F., \& Chandra, G. (2011). Service, Quality \& Satisfaction. In Edisi 4.

van Griethuijsen, R. A. L. F., Kunst, E. M., van Woerkom, M., Wesselink, R., \& Poell, R. F. (2019). Does implementation of competence-based education mediate the impact of team learning on student satisfaction? Journal of Vocational Education \& Training. https://doi.org/10.1080/13636820.2019.1644364.

Zvyagin, L. S. (2017). Competence modern teacher as a tool for assessing the quality of higher education. 2016 IEEE 5th Forum Strategic Partnership of Universities and Enterprises of Hi-Tech Branches, Science. Education. Innovations 2016. https://doi.org/10.1109/IVForum.2016.7835845. 